\title{
The income effect of a disabled child
}

\author{
DAVID PIACHAUD \\ From the Department of Social Science and Administration, London School of Economics and Political Science
}

\author{
JONATHAN BRADSHAW AND JANE WEALE \\ From the Social Policy Research Unit, University of York
}

SUMMARY Data from the General Household Survey were employed to compare the participation rates, hours worked, earnings, and net incomes of families with and without a disabled child. In families with a disabled child it was found that the spouse was significantly more likely to work the more children there were in the family and that income, and income as a proportion of supplementary benefit entitlement, was lower.

In 1974 the government published a White Paper on social security provision for the disabled. ${ }^{1}$ For adults this document presaged a package of new benefits including the invalid care allowance, the non-contributory invalidity benefit, and the mobility allowance. Except for the mobility allowance, no new benefits were to be paid to children.

It was recognised in the paper that the presence of a disabled child in a family can create financial needs in four ways: (i) it can prevent and/or reduce parents' earnings; (ii) it can involve payments for services that the parents might normally provide themselves; (iii) it can involve extra costs in providing for the child; and (iv) it can make additional physical and emotional demands on the parents which might be partially compensated for by cash.

The government resolved to sponsor research into these questions. The Social Policy Research Unit was already engaged in research into the income and expenditure effects of a disabled child ${ }^{2-6}$ and the Department of Health and Social Security commissioned from the unit an additional survey of the income and expenditure of families with disabled children compared with a control group of families from the Family Expenditure Survey. This research is still in progress. Meanwhile the Pearson Committee has reported, and one of its principal recommendations was that a general expenses allowance should be introduced to meet the extra costs it believed are entailed in caring for a disabled child. ${ }^{7}$

This article reports some new evidence on the income effects of a disabled child which has emerged from an analysis of data in the General Household Survey.

\section{Method and data}

The General Household Survey is a multipurpose survey which is carried out continuously and provides annual information on a nationally representative sample of the population of private households in Great Britain. The effective sample size varies a little from year to year but in 1974 , the year used for this analysis, the effective sample consisted of about 14200 private households and interviews were obtained at $86 \%$ of these households. ${ }^{8}$ Over the period from 1971, when the survey started, to 1976 , all respondents with children under 16 answered a child health schedule which included questions on chronic sickness. In 1974 the first of these questions was 'Do any of your children under 16 have any long-standing illness, disability or infirmity'?, followed by 'Does the complaint limit the child's activities in any way'? The analysis presented here is based on a comparison of households divided according to their answers to these questions.

The data relating to disability and handicap among children that are available from the General Household Survey have limitations because the survey was not primarily designed to provide information of this kind. The respondent, normally the parent, is the sole source of information about the child and is asked for a full description of the type of long-standing illness (this term will be used as a shorthand for the full phrase of the question) affecting the child and its cause, as well as the medical term for the illness if this is known. There is thus no medical assessment of the nature of the complaint and the information obtained from the respondents may not be complete or fully accurate. 
The information on the illness was coded by coders with some medical knowledge and experience who were able to assess the descriptions given and code them according to the International Classification of Diseases. ${ }^{\circ}$ No attempt was made, however, to validate the accuracy of the information provided by comparison with hospital records or those of the school health service or the general practitioner. Assuming that in the great majority of cases the information provided by the respondent is accurate, the General Household Survey thus provides reasonable data on the disease, disorder or injury affecting the children.

Knowledge of the children's complaints does not, however, give an indication of the degree of disability; many of the complaints affecting the children would not give rise to severe disabilities. To estimate the degree of disability, other information was used. The survey provides information on whether the illness limits the child's activities in any way and on the extent to which the child is able to get out of the house; there is information available on the length of time for which the complaint had been limiting, the child's age, the nature of the school attended (in particular whether it was a special school or not), in addition to the $I C D$ coding for the long-standing illness. All this information was used by a consultant paediatrician with much experience of disability in children to classify the children as severely, moderately, or mildly disabled. An analysis has already been published of the data on the types and severity of disability and some of the sociodemographic characteristics of the families. ${ }^{10}$

The General Household Survey includes questions on the income and economic circumstances of members of the household. This present analysis was made possible because of the availability of a data tape prepared by the Centre for Labour Economics for the analysis it carried out for the Royal Commission on the Distribution of Income and Wealth. ${ }^{11}$ Its published analysis was based on the 1975 General Household Survey but as a preliminary it had also edited and prepared the income data for the 1974 General Household Survey.

In order to combine data on child disability with data on incomes, two sets of data had to be merged. The families with disabled children were identified on the income tape; data on the severity of disabilities were added to each case record. For the definitions of income used in this analysis readers are referred to Chapter 2 and the Annex of Layard et al. ${ }^{11}$

The analysis presented here is restricted to a subset of families. There were 653 children identified as having long-standing illness, disability or infirmity in the 1974 General Household Survey sample-63 severe, 184 moderate, and 406 mild. These children were in $\mathbf{5 7 9}$ households. Two of these households contained more than one family with children so that it was not known which family had this disabled child. A further 149 families were excluded because the income data were inadequate. The proportion of families with various levels of severity of disability left in the study was not significantly different from the original sample distribution. It has been assumed that any other possible bias introduced into the sample by non-response to the income question is independent of having a disabled child and affects the disabled and non-disabled family equally.

In order to eliminate factors which may have a different significance for the families with a disabled child and to restrict the analysis to groups where the sample sizes might be adequate and comparable the following families were also excluded:

Families in households containing more than one family unit.

One-parent families.

Families with a dependent child aged 16 or over.

Families where the woman was aged under 25 or over 55 .

Thus the analysis was based on two-parent families living in single family households in which the woman was aged between 25 and 55 and all the children were under 16 . The analysis covered 1665 families with no disabled children, 187 with a mildly disabled child, 89 with a moderately disabled child, and 27 with a severely disabled child. Where there was more than one disabled child, categorisation is based on the most severely disabled child.

For some of the analyses it was appropriate to restrict the sample still further. Thus, even though the General Household Survey has a large sample, the number of families with severely handicapped children is small. This limitation must be recognised at the outset: a large survey is being used for a very specialised purpose for which it was not specifically designed.

\section{THE HYPOTHESES}

The following hypotheses about the possible income affects of a disabled child have been examined.

\section{(1) Labour force participation}

The proportion of families in which the head of the family or the spouse is in paid work could be different when there is a disabled child. The extra costs of caring for a disabled child might provide an additional incentive to work for men and women who might otherwise remain at home. On the other hand, the parents of a disabled child may be less likely to go out to work, mothers because of the extra burdens of care and fathers because of anxiety about leaving their spouses during the day to care for the child unaided. 


\section{(2) Hours worked}

The hours worked by those who do participate in the labour force could be different when there is a disabled child. Again, the extra costs of caring for a child could provide an incentive to work longer hours or a lower participation rate by wives could result in husbands working longer hours to make up for the income foregone. The hours worked by parents of a disabled child could be lower: the wife may have to take part-time instead of full-time work to be at home to care for the child and the husband's working patterns may be interrupted by the need to get home in emergencies in order to help.

\section{(3) Earnings}

The earnings of families with a disabled child may be different from those of families with normal children. This may be the effect of lower labour force participation or because fewer hours are worked, but it could also occur independently. Families with disabled children could have lower earning potential because they have less skill, education, and training. They may also have lower earnings because they decide to refuse promotion and responsibility, either in order to be available to help at home or because they would have to move to another area with fewer support services.

\section{(4) Income}

The income of families with a disabled child may differ from that of families with normal children because of differences in earnings, but this may be made up in whole or in part through social security benefits or tax concessions.

\section{Results}

\section{MEN'S WORK}

The labour force participation, weekly hours, hourly earnings, and annual earnings of men are shown in Table 1 . The results may be summarised briefly: there are no significant differences between families with disabled children and those without for all families or after controlling for family size. There are, of course, differences, but based on an analysis of variance, none of them are significant at the $95 \%$ confidence level. Virtually all the men were in the labour force.

\section{WOMEN'S WORK}

The participation rates and earnings of women were, for all the groups, much lower than those of men. Women's participation is related to many factors, but the most important influence is the age of the youngest child in the family. ${ }^{11}$ Taking children of all ages together, there was no detectable influence of the child's disability on women's work.

When the analysis is confined to families where the youngest child is aged 6 or over, and controlling for family size, as shown in Table 2 , certain significant differences emerge. In one-child families participation and hours are much lower when there is a moderately or severely disabled child, whereas in three-child families the reverse is true. The degree of significance of the differences in families with one, two, and three or more children were $0 \cdot 04,0 \cdot 84$, and $0 \cdot 16$ respectively. Only for one-child families was the difference significant at the $5 \%$ level, but there was an indication that in families with a disabled child paid

Table 1 Man's paid work-children of all ages

\begin{tabular}{|c|c|c|c|c|c|}
\hline & $\begin{array}{l}\text { Proportion } \\
\text { participating }\end{array}$ & $\begin{array}{l}\text { Mean } \\
\text { weekly } \\
\text { hours }\end{array}$ & $\begin{array}{l}\text { Mean } \\
\text { hourly } \\
\text { earnings (pence) }\end{array}$ & $\begin{array}{l}\text { Mean } \\
\text { annual } \\
\text { earnings (f) }\end{array}$ & No. \\
\hline $\begin{array}{l}\text { ALL SIZES OF FAMILY } \\
\text { No disability } \\
\text { Mild disability } \\
\text { Moderate disability } \\
\text { Severe disability } \\
\text { Moderate or severe disability }\end{array}$ & $\begin{array}{l}0.99 \\
0.99 \\
0.97 \\
1.00 \\
0.97\end{array}$ & $\begin{array}{l}46 \cdot 5 \\
46 \cdot 3 \\
47 \cdot 6 \\
47 \cdot 0 \\
47 \cdot 4\end{array}$ & $\begin{array}{l}123 \\
120 \\
111 \\
113 \\
112\end{array}$ & $\begin{array}{l}2420 \\
2284 \\
2255 \\
2234 \\
2250\end{array}$ & $\begin{array}{r}1665 \\
187 \\
89 \\
27 \\
116\end{array}$ \\
\hline $\begin{array}{l}\text { ONE-CHILD } \\
\text { No or mild disability } \\
\text { Moderate or severe disability }\end{array}$ & $\begin{array}{l}0.98 \\
1.00\end{array}$ & $\begin{array}{l}45 \cdot 7 \\
48 \cdot 2\end{array}$ & $\begin{array}{l}118 \\
101\end{array}$ & $\begin{array}{l}2357 \\
2248\end{array}$ & $\begin{array}{r}515 \\
14\end{array}$ \\
\hline $\begin{array}{l}\text { TWO-CHILD } \\
\text { No or mild disability } \\
\text { Moderate or severe disability }\end{array}$ & $\begin{array}{l}0.99 \\
0.98\end{array}$ & $\begin{array}{l}46 \cdot 4 \\
46.9\end{array}$ & $\begin{array}{l}124 \\
124\end{array}$ & $\begin{array}{l}2459 \\
2452\end{array}$ & $\begin{array}{r}828 \\
51\end{array}$ \\
\hline $\begin{array}{l}\text { THREE-CHILD } \\
\text { No or mild disability } \\
\text { Moderate or severe disability }\end{array}$ & $\begin{array}{l}0.99 \\
0.93\end{array}$ & $\begin{array}{l}47 \cdot 4 \\
51 \cdot 2\end{array}$ & $\begin{array}{l}127 \\
107\end{array}$ & $\begin{array}{l}2391 \\
2104\end{array}$ & $\begin{array}{r}331 \\
27\end{array}$ \\
\hline $\begin{array}{l}\text { FOUR-CHILD } \\
\text { No or mild disability } \\
\text { Mild or severe disability }\end{array}$ & $\begin{array}{l}0.99 \\
1.00\end{array}$ & $\begin{array}{l}47 \cdot 1 \\
43.4\end{array}$ & $\begin{array}{r}122 \\
94\end{array}$ & $\begin{array}{l}2435 \\
1869\end{array}$ & $\begin{array}{r}135 \\
12\end{array}$ \\
\hline
\end{tabular}


Table 2 Woman's paid work-youngest child aged 6 or over

\begin{tabular}{|c|c|c|c|c|c|}
\hline & $\begin{array}{l}\text { Proportion } \\
\text { participating }\end{array}$ & $\begin{array}{l}\text { Mean } \\
\text { annual } \\
\text { hours }\end{array}$ & $\begin{array}{l}\text { Mean } \\
\text { hourly } \\
\text { earnings (pence) }\end{array}$ & $\begin{array}{l}\text { Mean } \\
\text { annual } \\
\text { earnings (f) }\end{array}$ & No. \\
\hline \multicolumn{6}{|l|}{ ALL SIZES OF FAMILY } \\
\hline No disability & 0.67 & 755 & 71 & 517 & 775 \\
\hline Mild disability & 0.78 & 741 & 89 & 539 & 88 \\
\hline Moderate disability & 0.70 & 724 & 77 & 481 & 50 \\
\hline Severe disability & 0.64 & 846 & 64 & 560 & 11 \\
\hline Moderate or severe disability & 0.69 & 746 & 75 & 496 & 61 \\
\hline \multicolumn{6}{|l|}{ ONE-CHILD } \\
\hline No or mild disability & 0.70 & 847 & 73 & 576 & 288 \\
\hline Moderate or severe disability & 0.40 & 171 & 109 & 181 & 10 \\
\hline \multicolumn{6}{|l|}{ TWO-CHILD } \\
\hline No or mild disability & 0.68 & 698 & 68 & 488 & 393 \\
\hline Moderate or severe disability & 0.70 & 763 & 85 & 549 & 33 \\
\hline \multicolumn{6}{|l|}{ THREE-CHILD } \\
\hline No or mild disability & 0.67 & 760 & 92 & 517 & 129 \\
\hline Moderate or severe disability & 0.89 & 1093 & 55 & 641 & 9 \\
\hline \multicolumn{6}{|l|}{ FOUR-CHILD } \\
\hline No or mild disability & 0.70 & 687 & 64 & 451 & 44 \\
\hline Moderate or severe disability & 0.60 & 678 & 44 & 299 & 5 \\
\hline
\end{tabular}

work increased with family size, whereas in other families it showed little relation to family size. A specific test of this was carried out by regressing women's participation, hours, and annual earnings on number of children, as shown in Table 3. Where there was mild disability or none, only women's hours were significantly related to family size and then negatively. Where there was a moderately or severely disabled child both participation and hours were significantly and positively related to family size.

There are three possible explanations for this finding. Firstly, women may find it easier to work part-time when there are other children available to care for the disabled child in their absence. Secondly, the pressure on resources in larger families may be such as to make it essential for women to work. Thirdly, women with larger families may be more inclined to work to gain respite from home life.

Table 3 Woman's paid work-youngest child aged 6 or over

\begin{tabular}{|c|c|c|c|c|}
\hline \multicolumn{5}{|c|}{ NO OR MILD DISABILITY } \\
\hline Woman's participation & & $\begin{array}{l}-0.014 N^{*} \\
(0.018)\end{array}$ & $\begin{array}{c}+0.713 \\
(0.038)\end{array}$ & $r^{2}=0.001$ \\
\hline Woman's hours & & $\begin{array}{c}-61.3 N \\
(29.6)\end{array}$ & $\begin{array}{r}+873.2 \\
(63.3)\end{array}$ & $r^{2}=0.005$ \\
\hline Woman's earnings & & $\begin{array}{l}-37.3 N^{*} \\
(22.6)\end{array}$ & $\begin{array}{c}+592.7 \\
(48.4)\end{array}$ & $r^{2}=0.003$ \\
\hline \multicolumn{5}{|c|}{ MODERATE OR SEVERE DISABILITY } \\
\hline Woman's participation & & $\begin{array}{l}0.106 N \\
(0.053)\end{array}$ & $\begin{array}{r}+0.438 \\
(0.138)\end{array}$ & $r^{2}=0.063$ \\
\hline Woman's hours & & $\begin{array}{l}222 \cdot 7 \mathrm{~N} \\
(90 \cdot 0)\end{array}$ & $\begin{array}{r}+220.6 \\
(234.4)\end{array}$ & $r^{2}=0.094$ \\
\hline Woman's earnings & & $\begin{array}{l}84.9 \mathrm{~N}^{*} \\
(64.9)\end{array}$ & $\begin{array}{r}+295.3 \\
(169.2)\end{array}$ & $r^{2}=0.028$ \\
\hline
\end{tabular}

$\mathrm{N}$ is number of children in family.

Standard errors in brackets.

*Not significant at $5 \%$ confidence level.

\section{FAMILY INCOMES}

To the earnings of the man and woman is added income from benefits such as child benefit, social security benefit, and, for some families with severely disabled children, the attendance allowance. From their gross income, income tax, national insurance contributions, and housing costs are deducted to obtain net income. The effects of these additions and deductions are shown in Table 4. As a result of the cumulative effect of differences in participation rates, hourly earnings, and annual earnings, families without disabled children have higher earnings than families with disabled children, earnings being lower the more severe the disability. These differences in earnings are almost evened out by the operation of state benefits. Unfortunately the General Household Survey does not distinguish between the attendance allowance and other benefits. It is probable that the larger contribution from state benefits for families with severely disabled children is due to the attendance allowance. It should be noted that the attendance allowance, treated here as income, is not strictly an income replacement benefit. Its purpose is not altogether clear but it has more to do with meeting the extra expenses associated with disability than with compensating for income losses. ${ }^{12}$ If it had been possible, it would perhaps have been more appropriate to discount the effects of the attendance allowance in this analysis.

The actual value of income depends on the number of people it has to support, so in order to make a real comparison of living standards it is necessary to control for family size. This can be done by using equivalence scales, or by expressing income as a proportion of the supplementary benefit entitlement 
Table 4 Family income-children of all ages

\begin{tabular}{|c|c|c|c|c|c|c|c|}
\hline & $\begin{array}{l}\text { Mean } \\
\text { earnings } \\
\text { of man }\end{array}$ & $\begin{array}{l}\text { Mean } \\
\text { earmings } \\
\text { of woman }\end{array}$ & $\begin{array}{l}\text { Mean } \\
\text { social } \\
\text { security }\end{array}$ & $\begin{array}{l}\text { Mean } \\
\text { gross } \\
\text { income }\end{array}$ & $\begin{array}{l}\text { Mean } \\
\text { net income } \\
\text { (after housing } \\
\text { costs) }\end{array}$ & $\begin{array}{l}\text { Mean } \\
\text { income as } \\
\text { proportion } \\
\text { of SB level }\end{array}$ & No. \\
\hline & $\varepsilon$ & $\varepsilon$ & $\boldsymbol{E}$ & $\boldsymbol{E}$ & $\boldsymbol{E}$ & & \\
\hline $\begin{array}{l}\text { ALL SIZES OF FAMILY } \\
\text { No disability } \\
\text { Mild disability } \\
\text { Moderate disability } \\
\text { Severe disability } \\
\text { Moderate or severe disability }\end{array}$ & $\begin{array}{l}2420 \\
2284 \\
2255 \\
2234 \\
2250\end{array}$ & $\begin{array}{l}344 \\
357 \\
360 \\
365 \\
361\end{array}$ & $\begin{array}{r}94 \\
107 \\
163 \\
235 \\
180\end{array}$ & $\begin{array}{l}3292 \\
3234 \\
3190 \\
3356 \\
3229\end{array}$ & $\begin{array}{l}2287 \\
2296 \\
2300 \\
2452 \\
2336\end{array}$ & $\begin{array}{l}2 \cdot 20 \\
2 \cdot 10 \\
2 \cdot 05 \\
2 \cdot 16 \\
2 \cdot 08\end{array}$ & $\begin{array}{r}1665 \\
187 \\
89 \\
27 \\
116\end{array}$ \\
\hline
\end{tabular}

Table 5 Family income relative to $S B$ level

\begin{tabular}{|c|c|c|c|c|}
\hline & Under $140 \%$ & $140-199 \%$ & $200 \%$-over & No. \\
\hline \multirow{2}{*}{$\begin{array}{l}\text { No or mild disability } \\
\text { Moderate or severe } \\
\text { disability }\end{array}$} & $12 \cdot 2$ & $37 \cdot 0$ & 50.8 & 1814 \\
\hline & $16 \cdot 5$ & $45 \cdot 2$ & $38 \cdot 3$ & 115 \\
\hline
\end{tabular}

$x^{2}=7.52$ df $0.05>p>0.01$.

of a family of that size. The latter approach is adopted here, with the results shown in Table 5. It shows that incomes relative to supplementary benefit levels are significantly lower in families with a disabled child, even including the attendance allowance.

\section{Conclusion}

It has been suggested that the presence of a disabled child in a family may affect the household financially, by limiting earning power and by altering the pattern of expenditure. This analysis has dealt exclusively with the income effects. More detailed analysis of the expenditure (and income) effects must await the results of research commissioned by the Department of Health and Social Security and now in progress.

The results of this analysis suggest that a disabled child does not have a clear-cut dramatic effect on the parents' paid work and income. In two-parent families no clear differences existed in the man's working or in his earnings. Among women, differences emerged only when younger children were excluded. In families without a severely disabled child the extent of women's working bore little relation to the number of children. But where there was a moderately or severely disabled child women appeared to work more when they had more children. This finding was statistically significant at the $5 \%$ confidence level.

The results consistently indicated lower average total incomes in families with disabled children and also lower incomes as a proportion of supplementary benefit entitlement.
We thank the Office of Population Censuses and Surveys for its help. However, responsibility for the analysis and interpretation of the data rests entirely with the authors. This work was supported by a grant from the Department of Health and Social Security.

Reprints from Dr. Jonathan Bradshaw, Social Policy Research Unit, University of York, Heslington, York YO1 5DD.

\section{References}

${ }^{1}$ House of Commons Paper No. 276. Social Security Provision for Chronically Sick and Disabled People. London: HMSO, 1974.

${ }^{2}$ Balwin SM. Families with handicapped children. In: Jones K, Baldwin SM, ed. The Yearbook of Social Policy in Britain, 1975. London: Routledge and Kegan Paul, 1976.

${ }^{3}$ Bradshaw JR. The Financial Needs of Disabled Children. London: Disability Alliance, 1976.

'Baldwin SM. The Cost of a Disabled Child. London: Disability Alliance, 1977.

${ }^{5}$ Bradshaw JR. Examining benefits for families with handicapped children. In: DHSS Social Security Research. London: HMSO, 1977.

-Bradshaw JR. The Family Fund, London: Routledge and Kegan Paul, 1980.

'Pearson Committee. Report of the Royal Commission on Civil Liability and Compensation for Personal Injury Vols I-III. Cmnd 7054. London: HMSO, 1978.

- Office of Population Censuses and Surveys. The General Household Survey 1974. London: HMSO, 1977.

- World Health Organisation. International Classification of Diseases, 8th revision, Geneva: WHO, 1967.

${ }^{10}$ Weale J, Bradshäw JR. Prevalence and characteristics of disabled children: findings from the 1974 General Household Survey. J Epidemiol Community Health 1980; 34: 111-8.

"Layard R, Piachaud D, Stewart M. The causes of poverty. Background Paper No. 5 to Report No. 6 of the Royal Commission on the Distribution of Income and Wealth. London: HMSO, 1978.

${ }^{12}$ Bradshaw JR, Lawton D. Examination of equity in the administration of the attendance allowance. Policy and Politics 1980; 8: 39-54. 